\title{
Awaiting the gypsy moth
}

\section{Washington}

Spring in New England, with its greenshaded campuses, tall shadowy and seemingly endless deciduous forests, and country villages with white church spires set against rolling green mountains, used to be one of the natural glories of North America. But as spring advances in New England this year, so will the gypsy moth (Lymantria dispar). During June and July the moths will emerge from their pupae and begin their destructive predatory march that now covers most of eleven states from Maine down to Maryland, munching away at the entire foliage of white, red, black and scarlet oaks, and in infested areas of the grey birch trees, the apple trees, American beeches, red maples and even conifers including the common white pine. In areas of heavy infestation, the upper ridges of mountains become so entirely denuded of tree canopy and ground cover that they are ashen and apparently lifeless, reminiscent, as one New Haven scientist said last week, of an experiment that Brookhaven National Laboratory ran in the 1950s to see what a forest would look like after irradiation by nuclear weapons.

The plague of the gypsy moth in the United States is a genetic experiment run wild. In 1869, L. Trouvelot, a French astronomer and naturalist who lived at 27 Myrtle Street, Medford, Massachusetts, imported some gypsy moths from Europe to help found a silkworm industry in New England, then the centre of the textile industry. Some of the eggs were lost, and by 1889 they had multiplied enough to provoke an outbreak in the town of Medford. The following year the state legislature awarded $\$ 25,000$ for control.

Things have got worse since. The larvae hang on silk threads they have spun, so that air currents can carry them to new trees in which to hatch. Prevailing winds encouraged the spread through northern New England. In 1923 the government established the north-south flowing Hudson River as a natural "barrier zone" to contain the spread south. The Second World War interrupted control efforts, but brought an apparent remedy: DDT. The 1950s saw uncontrolled spraying which checked the infestation in some places, but did not control the spread. In 1958, when DDT was banned, a less effective substitute Sevin was introduced and the government finally started a research programme to control the beasts.

Each year, the front of infestation moves westwards and southwards away from New England. Last year an estimated 13 million acres were defoliated, double the area in 1980. Estimates for the summer of 1982 are that yet another 13 million acres will be defoliated, that is, 50 per cent or more of the canopy will be destroyed by gypsy moths. Carried by vehicles, gypsy moths have been found in Ohio, North Carolina,
South Carolina, Virginia, West Virginia, Wisconsin and Michigan and outbreaks have been reported in Salem, Oregon, and Santa Barbara, California. New England forests are not lumbered extensively any more, but as forests in the south and west become infested, the economic costs of the gypsy moth plague will grow.

The battle against the gypsy moth has been hindered by two things. One is the fact that no major industry is affected - thus in Maine, for example, the localized infestations are less important politically than the spruce budworm infestation, which has hurt that state's timber industry for some years. A second impediment is that the US environmental movement, with its power to express issues forcefully, and arouse public opinion, has been lukewarm to the gypsy moth issue. Many environmentalists are more concerned about the potential toxicity of Sevin, a spray commonly used against the gypsy moths, than they are about the forest damage per se. Moreover, the fact that lesser infestations do not destroy a forest completely and that most of the trees affected are only "ornamental", gives the environmentalists grounds to argue that the problem is not so urgent. One suspects that they may also hesitate to decry the gypsy moth because if the plague were indeed extensive is it not only a few logical steps to argue that we should return to the only known substance that combats it - DDT? Many environmentalists may not want to start down that slippery road.

So far, the gypsy moth story is one of the failure of science and technology. As the old saying goes, if we can go to the Moon, why can't we beat the gypsy moth? The chief microbial pathogen used so far, BT (Bacillus thuringiensis), is not nearly as effective as DDT: it must be sprayed over a large area requiring that an entire neighbourhood should get together and spray at once; if rain or other weather changes interrupt the spraying, it does no good. The other remedies tried so far have been of little effect, partly because, by now, the infestation is so severe. Research has recently focused on pheromones and other specific chemical lures, but the results are not yet broadly applicable.

The biology of the gypsy moth raises several interesting biological questions. The population dynamics of the gypsy moth are not understood, with rises of population followed by collapse, perhaps because of the weather. The physiology of the single American species may throw light on its susceptibility to parasites, perhaps the best hope for control. The relative scarcity of Lymantria species in Europe as compared with East Asia suggests that the genus originated in the Far East. The hope is that the work now under way will suggest a species-specific pesticide for a pest that the US Department of

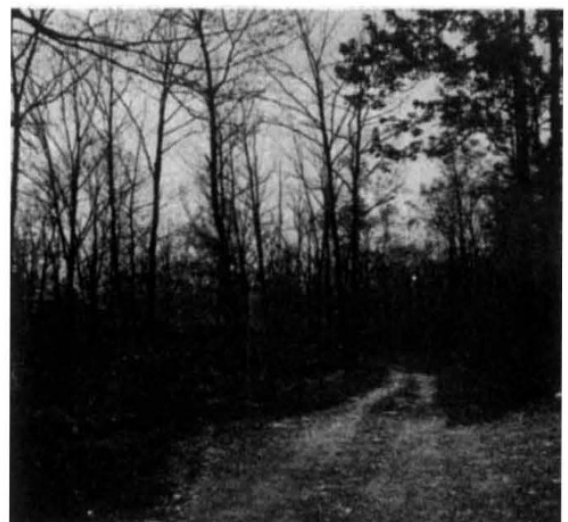

Upland oaks in New England heavily defoliated by the gypsy moth.

Agriculture acknowledges to be uncontrollable. The chemical company that first finds a cure will make a fortune. The search for parasites effective against gypsy moths has now turned to East Asia.

The pest also haunts Europe, but because the forests are less dominated by oak and are smaller and more precisely managed, it has not become the plague it is in the United States. Moreover, in Europe, the parasites that limit the gypsy moth population survive the winter whereas, when introduced into the United States, they die for lack of a suitable winter host.

China is the only part of the world that has not been thoroughly investigated for parasites that could solve the problem in the United States. It is to be hoped, therefore, that the Chinese government will be as cooperative as possible with the teams from the US Department of Agriculture which are there now, and plan to go again next year, to investigate gypsy moths in China, particularly in allowing parasites to be taken out of the country.

It is also to be hoped that the Reagan Administration will produce a better research policy on the gypsy moth than its parsimony so far suggests. The research programme begun by the Department of Agriculture in the 1970s may for practical purposes be abandoned as a consequence of the budget cuts. Aid to affected states on research and control, to which the federal government used to contribute 43 per cent, was cut for the present fiscal year to 12.5 per cent, although the Administration relented three weeks ago, and raised the proportion to 25 per cent. But in the coming financial year the Department of Agriculture will not be allowed to embark on any joint programmes with the states, although it may continue with some research of its own.

As New Englanders sit on their porches this spring, musing on how much the gypsy moth will devour of scrub oak or aspen trees on the West Coast, they can take some morbid pleasure in reminding themselves that their President thinks this is a local problem, and that his science adviser, for all his talk about the importance of science's interface with society, does not think the gypsy moth is of any priority for science.

Deborah Shapley 